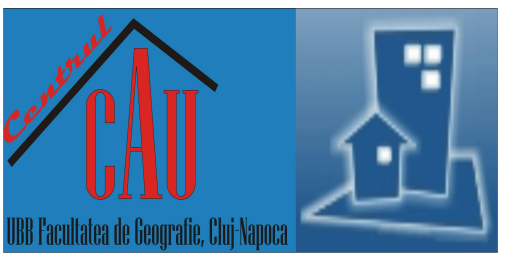

\title{
A Tripartite Approach to Ensure Municipal Service Delivery. The Case of a Mining Town in South Africa
}

\author{
Maléne CAMPBELL1, Ernst DREWES² \\ 1 University of the Free State, Faculty of Natural and Agricultural Sciences, Department of Urban and Regional Planning, \\ Bloemfontein, SOUTH AFRICA \\ ${ }^{2}$ North-West University, Faculty of Natural and Agricultural Sciences, Department of Urban and Regional Planning, Potchefstroom, \\ SOUTH AFRICA \\ E-mail: campbemm@ufs.ac.za, ernst.drewes@nwu.ac.za \\ DOI: 10.24193/JSSP.2018.2.02 \\ https://doi.org/10.24193/JSSP.2018.2.02
}

K e y w o r d s: service delivery, small town, spatial planning, mining, sustainability

\begin{abstract}
A B S T RA C T
Postmasburg, a small mining town, has been an agricultural centre for the past 120 years, the iron ore mining being the only diversifying factor to the local economy. Mining endeavours resulted in the traditional boom-town cycle in Postmasburg over the past ten years with one significant exception to most of the rural towns in South Africa, which experienced the same expansions in mining operations. Whereas the other towns ran into a bottleneck after the initial rounds of urban development, mainly as a result of insufficient bulk infrastructure and capable human resources, the Tsantsabane Local Municipality, within which the town of Postmasburg is located, together with the two listed mining companies Kolomela and Assore's Beeshoek, formed a tripartite partnership that approached service delivery in an exceptional manner. This paper critically assesses the Tsassamba Partnership against the background of the need for a partnership approach of governance against the background of the emphasis of planning theory on partnerships and local context. Data was collected by conducting interviews with representatives of the mining companies, municipality, business sector and civic organisations and quantitative questionnaires were applied in a household survey of 1,024 households. All the interviewees highlighted the success of this partnership approach. The survey also found that the partnership participated and cooperated successfully in the development of bulk infrastructure and land for housing for the mining employees, which had posed a major challenge to the local municipality.
\end{abstract}

\section{INTRODUCTION}

Towns can be clustered in ways that reveal their similarities, as in the case of mining towns [1]. Mining towns provide services to the communities of their surrounding areas, services, which may no longer be available to those communities, should the town decline as a result of the mine closing down [2]. A study which drew attention to the fulfilment of Germany's human rights commitments in the South African coal sector, questioned whether it is only the extraction of the natural resources that should be considered [3]. It investigated issues such as the constitutional right to housing and municipal services [4]. Taking these various points into consideration, and in the case mines have to downscale in future, the purpose of this paper is to determine whether the tripartite partnership's contribution and provision of municipal services could ensure the long-term sustainability of the small town of Postmasburg, which currently relies mainly on one primary activity, namely, mining.

Postmasburg has been an agricultural centre for more than 120 years, with one mining operation as the only diversifying factor in the local economy. In the 
1930s, Assore Limited, which jointly controls the manganese mines of Assmang Limited, opened a mine in Beeshoek, a rural hamlet about 15 kilometres from Postmasburg [5]. It was only in 2008, approximately 70 years later, after a significant increase in ore prices, that other mining companies such as Anglo American's Kumba Iron Ore Limited (Kolomela) showed interest in this region for expansion of their operations [5]. Over the past ten years these endeavours resulted in a traditional 'boom-town cycle' in Postmasburg; with one significant exception. In contrast to the experiences of most mining towns in South Africa, in the wake of expansions in mining operations, Postmasburg was able to avoid the usual bottle-neck after the initial rounds of urban development. Where other towns ran into challenges, mainly as a result of insufficient bulk infrastructure and lack of capable human resources at municipal level, the Tsantsabane Local Municipality, within which the town of Postmasburg is located, together with the two mining companies listed on the Johannesburg Stock Exchange (JSE), Kumba's Kolomela and Assore's Beeshoek, formed a tripartite partnership that approached development in an exceptional manner [5]. The South African Municipal Structures Act lays provisions for three categories of local authorities, namely: Metropolitan Municipalities, Local Municipalities and District Municipalities [6].

The tripartite alignment was named the Tsassamba Partnership. The partnership functioned at management and technical levels, with official representation of all three partners. Through this partnership a bank account was opened into which private companies and government departments deposited their financial contributions for the town's development. After a needs analysis, the town's future needs were translated into bulk services needs as well as land needs, which in turn were translated into plans and projects to be rolled out and managed by the Tsassamba Partnership.

\section{THEORETICAL PERSPECTIVE}

Local government is the sphere of government tasked with dealing with all matters relating to planning and development within its promulgated municipal boundary [6]. As such, the local government is an organ of state geared to providing policy and services within timeframes and according to scales required by industry. Industry, in turn, is driven by the global market place, and in this case study, commodity prices. A case in point is the chairperson of Anglo American, Sir Johan Parker's announcement that Anglo America considers selling more of its South African assets. He stated the obvious reason, namely that Anglo America's focus is on their best quality assets, which have attractive profit margins and deliver appealing yields on investments [7]. As the principal global role-players in the mining industry, the two mining companies represented in the Tsassamba Partnership face the challenge of competing with the global market during the positive phase of a commodity cycle, while also dealing with the administrative and resource restraints that characterise the local governments in rural areas in South Africa.

Planning theory increasingly emphasises on partnerships and collaboration [8]. The United Kingdom has seen the spread of collaborative governance and various forms of partnerships in community development are becoming common in other parts of the world, including North America. Healy (2006) recommends that planning and policymaking be based on interactive social processes [8]. Hillier and Gundler (2003) state that urban planning is, after all, about the city of the future and its impact on people [9]. However, Watson (2009) argues that neither communities nor the market will solve urban problems [10]. The implementation of plans should ideally be a process of negotiation and compromise [8]. Planners must understand the local dynamics and context and assess the impact of interventions on people.

Van Horen (2002) describes a participatory project aimed at social empowerment that was successfully implemented by GTZ (Gesellschaft für Technische Zusammenarbeit) in a war-torn area of Sri Lanka [11]. He argues that long-term improvement depends on the extent to which institutional capacity is built. The project's dependence on financial support was a problem as it meant that the development process might not be sustainable once the funding was exhausted. This problem was addressed by building connections on an understanding of local relationships and institutions. Relationships between the project and the central government were also positive and participatory on a local as well as central government level.

\subsection{Literature and policy on Public Private Partnerships}

Suitable procurement vehicles are required for the execution of projects that make Public Private Partnerships (PPPs) a viable option but the experiences of PPPs internationally were not all positive [12]. To address their large infrastructure gaps many countries find in PPPs a solution to finance infrastructure projects [13] and this justifies PPPs as they allow for the release of public funds. A main characteristic of a PPP, in comparison to conventional provision, is that it places investment together with service provision in one longterm contract. Other characteristics are: bundling of tasks, such as design and finance, and risk transfer [12]. The factors identified as contributing to successful PPPs are, amongst others: a strong private consortium, 
political and public support, as well as transparent procurement [14]. PPPs are also known as P3s and, in the United Kingdom, they are mostly called PFIs (Private Finance Initiatives).

The Royal Institute of Chartered Surveyors' (RICS) Policy Report contains their views on PPPs. They identify the need for PPPs as evolving in response to the new economic environment with tighter credit conditions and less government spending [15]. For this Policy Report, PPPs around the world were investigated, with special reference to the United Kingdom, Australia, the United States of America and Canada. The observations made in the report contain recommendations pertaining to the future use of PPPs and many of them are strongly focused on financial viability and project control. Australia is presently hailed by many as the leading country regarding PPPs. The National Public Private Partnership Guidelines of the Australian Government reflect that infrastructure is the main focus of PPPs with the private sector providing design, construction, financing, maintenance and delivery [16]. The government contributes with land, capital works, risk sharing, revenue diversion, purchasing of agreed services. The document also states that PPPs are not synonymous with privatisation, however, Engel et al (2013) argue that PPPs have several attributes typically associated with privatisation including that, as in PPPs, the concessionaire owns assets [12].

PPP Canada (2010-2011) was founded as a Crown Corporation with an independent board of directors [17]. Its mandate is to improve the delivery of public infrastructure by achieving better value, timelines and accountability to taxpayers through PPPs. PPPs are utilised by the federal government, and are also increasingly being viewed more favourably by provincial governments in Canada. PPP Canada (20102011) emphasises on financial viability and project control as it reflects that PPPs are delivering a broad range of on-time, on-budget public infrastructure projects, including transportation, reducing risk and maximising value over the entire project life cycle [17]. It offers integrated solutions regarding design, construction, finance and operation of public infrastructure. PPPs draw leading expertise together in all aspects, using competition and capital markets to ensure private sector delivery.

Ndoni and Elhag (2012) report the following main barriers to innovation in PPP projects in the United Kingdom: their once-off nature; the configuration of construction work; a lack in joint collaboration; and challenges to management innovation [18]. As possible corrective measures they identify: formation of interpersonal ties; networks of learning; and joint collaboration between clients, suppliers, manufacturers and researchers. Some key ingredients have been identified as missing in PPPs, namely how to stimulate innovation and other factors of significance.

\subsection{Sustainable human settlements}

The Habitat Agenda (1996) placed great emphasis on the development of sustainable human settlements that should be planned, developed and improved in a manner that takes full account of sustainable development principles and all their components [19]. These development principles included concepts and theories of social integration, combating segregation, improved access to opportunities, promoting geographically balanced settlements and more sustainable human settlement with housing that is more integrated, as well as including access to transport and social facilities. This was reiterated in the recent Habitat III document, which places an even stronger emphasis on the supply of housing in a sustainable and integrated manner [20]. This implies a more sustainable location with the necessary ancillary services such as infrastructural and social amenities to support the community, with the desired effect of urban resilience [21]. This reflection on international policy and best practice formed the backdrop to a process whereby the mining industry agreed to a tripartite structure that approached service delivery in an exceptional manner.

Various policy and legislative guidelines broadly referred to the prominence of mining villages [21]. The White Paper on the Energy Policy states that the structure of mining towns must be altered to integrate mineworkers into the local economy and to end the racial segregation of mineworkers [22]. It further proposes that a tripartite structure should be established among the state, the mining industry and representatives of employees' labour unions to seek ways and means of improving the lot of workers who live on the mines and to investigate the issue of housing and accommodation for workers and their families at mines, with due regard for the continued viability of communities thus established.

Little coordination exists between the many South African government departments that implement spatial programmes [23]. In the National Spatial Development Perspective (NSDP) (2012) the government calls for mine companies to ensure empowerment of employees through home ownership and to move away from providing housing at unsustainable locations on mine land [24]. The NSDP further encourages mining companies to ensure that housing development is promoted in sustainable towns near the mining operations and not as isolated villages on mine-owned land.

The above-mentioned policy guidelines assisted in convincing the mining companies to identify Postmasburg as a town-of-choice although the 
institutional capacity was potentially lacking. With an envisaged development project of more than 2000 new houses and supporting bulk as well as internal infrastructure in the relevant rural town, comprising only 6600 households at the time, the main challenge was increased institutional capacity and support. This gave birth to the need for a 'vehicle', which would then manage all the parties' needs in an efficient and legal manner. As mentioned, a local municipality must provide for the necessary 'development function' in terms of providing physical infrastructure and community services. According to Section 153 of the Constitution (1998) a municipality “... must structure and manage its administration and budget and planning processes to give priority to the basic needs of the community, and to provide for the social and economic development of the community" [6]. In addition, specific functions have been allocated to a Category B Municipality, such as Postmasburg, in terms of Section 83 of the Municipal Structures Act, amongst others, to execute (i) integrated development planning; and (ii) bulk infrastructure and service development [5].

One of the development principles of the South African Spatial Planning and Land Use Management Act (SPLUMA) is spatial justice. This principle, which is unique to South Africa, has to be promoted and implemented in conjunction with others in previously excluded areas, disadvantaged areas and areas of deprivation [24].

\section{METHODS}

The general organising framework or methodological paradigm for this paper is founded on interpretive social science, i.e. analysing the reality of spatial planning and public management in a meaningful manner. Considering the interpretive nature of this research, the methodological approach was primarily based on qualitative interviews and a case study, which was evaluated as part of the research design. It is well known that a case-study approach to research design is a scientifically accepted method for the cumulative development of knowledge and compares well to other methods of research design [26]. In addition, a case study is a useful research design when exploring an area with a view to gaining an holistic understanding of the specific situation or community. In this research a tripartite approach, designed, established and implemented in a unique manner, becomes the basis of a holistic and in-depth exploration of a municipal management partnership.

Methods of qualitative data collection included scrutiny of minutes of municipal meetings, reviewing contracts and tender documentation, in-depth interviews, and personal observations. Data was collected by conducting 28 semi-structured interviews with key informants from mining companies, the municipality, the business sector and civic organisations. Although these respondents were initially sampled purposively, the interviewers talked to every business person, municipal official, mining employee and community leaders who agreed to be interviewed.

Secondly, quantitative questionnaires were served in a household survey of 1,024 households in all areas of Postmasburg. The majority of households, 529 in total, responded that they were employed in mining, 273 responded that they were from non-mining households and 222 were part of informal settlements around Postmasburg. This research started in 2015 and ended in 2016. To obtain the samples for the mining houses, random sampling was applied based on cadastral information. For the informal settlements, random cluster sampling was applied by dividing these settlements into eight sub-areas. At least 20 of the 1,024 questionnaires were not fully completed. These incomplete questionnaires were included when the number of respondents that refused to answer a question were calculated, which pushed up the numbers of the 'refused to answer category' for each question by at least $2 \%$.

\section{RESULTS AND DISCUSSION}

It is important to provide a spatial perspective on Postmasburg, which is situated in one of the largest of the nine provinces in South Africa but is also the most sparsely populated, with the lowest human density indexes. It is positioned in a dry and arid region, being classified as part of the Kalahari Desert; this is part of the huge sand basin that reaches up to Angola in the west and to Zimbabwe in the east [27]. The Kalahari is known for the unique aesthetic appeal of its red dune landscape and it includes several smaller settlements. These are scattered all over the region and were established mainly near mineral deposits.

The economic history of the region has evolved and developed upon a rich base of mineral resources, particularly diamond, copper, manganese and iron ore deposits. Legislative changes at national level regarding the management and utilisation of South Africa's mineral endowments provided the region with a number of opportunities for catalysing future growth and development around this resource base [28]. The challenge recognised for most towns and villages in the region was to switch from a singular economic base and engage in a multi-dimensional approach to spatial planning and development that goes beyond single perspectives on economic growth, infrastructure provision and poverty alleviation [29]. The provincial regional growth and development strategy called for a socio-spatial approach to planning, taking into account the need for a place-making approach, while 
simultaneously considering the bigger whole and the public good, both on short term and over the long run. This implied flexible yet institutional readiness and capacity in governance to ensure a balance between short-term needs and long-term visions and costs.

In 2008, when the Tsassamba Partnership was formed, Postmasburg was an isolated town in this desert-like region with an economic base mostly focused on mining and agriculture. It also illustrated a relatively capable institutional resource at the local administration level but was unfortunately a low priority investment zone for provincial government. Between 2001 and 2011 the population increased by 30,089 (42\%) and between 2011 and 2015 by an estimated 35,00o (14\%). A national household survey conducted in 2011 involved 800 families (a sample of 10\%) in the Tsantsabane Local Municipality. The majority, namely $55.5 \%$ of these heads of households, were employed, which is well below the current national average of $73.4 \%$, which includes the metropolitan areas with better employment opportunities [30].

\subsection{Quantitative survey analysis}

The empirical quantitative survey, however, showed that at least $68.7 \%$ of the sample population was employed (Table 1). The national household survey also indicated that the highest percentage of families, namely 53.3\%, earned less than 38,401 South African Rand (ZAR) which is approximately2 403 Euro (EUR) annually, which puts them into the low-income bracket, below 42,001 ZAR per annum which means approximately 2,628 EUR [30]. Low-income families earning up to 42,000 ZAR qualify for the Reconstruction and Development Programme's (RDP) once-off project-linked subsidy, which applies to families earning up to 3,500 ZAR, which is about 219 EUR/month [31].

Table 1. Income from employment (wages/ salaries/ commission) received at the end of the previous month.

\begin{tabular}{l|rr}
\multicolumn{1}{c|}{ Response } & Number of respondents & \multicolumn{1}{c}{$(\boldsymbol{\%})$} \\
\hline Yes & 703 & 68.7 \\
No & 292 & 28.5 \\
Refused & 26 & 2.6 \\
Don't know & 3 & 0.3 \\
Total & $\mathbf{1 0 2 4}$ & $\mathbf{1 0 0}$
\end{tabular}

A question was asked to determine whether the respondents accessed housing through the abovementioned RDP programme (Table 2). The vast majority of them (68.5\%) did not have RDP houses, while one respondent indicated that they received the once-off subsidy twice - which is a concern.

The vast majority of the sampled families (72.8\%) live in formal permanent structures such as brick and mortar houses, apartment blocks, town houses or a retirement village, while $25.2 \%$ live in informal structures with limited services (Table 3 ).

Table 2. Number of households receiving government assistance (e.g. RDP housing) to obtain their dwellings.

\begin{tabular}{l|rr}
\multicolumn{1}{c|}{ Response } & Frequency & \multicolumn{1}{c}{$(\boldsymbol{\%})$} \\
\hline Yes, for this dwelling & 281 & 27.4 \\
Yes, for another dwelling & 8 & 0.8 \\
Yes, for this and another dwelling & 1 & 0.1 \\
No & 702 & 68.6 \\
Refused to answer the question & 30 & 3.0 \\
Don't know & 2 & 0.2 \\
Total & $\mathbf{1 0 2 4}$ & $\mathbf{1 0 0}$
\end{tabular}

Table 3. Type of main dwellings of the household.

\begin{tabular}{|c|c|c|}
\hline Response & Frequency & $(\%)$ \\
\hline $\begin{array}{l}\text { Dwelling/house or brick structure } \\
\text { on a separate stand or yard or on } \\
\text { farm }\end{array}$ & 696 & 68.0 \\
\hline $\begin{array}{l}\text { Traditional dwelling/hut/structure } \\
\text { made of traditional materials }\end{array}$ & 1 & 0.1 \\
\hline $\begin{array}{l}\text { Flat or apartment in a block of } \\
\text { flats }\end{array}$ & 4 & 0.4 \\
\hline $\begin{array}{l}\text { Town/cluster/semi-detached } \\
\text { house (simplex, duplex or triplex) }\end{array}$ & 16 & 1.6 \\
\hline Unit in retirement village & 1 & 0.1 \\
\hline $\begin{array}{l}\text { Dwelling/house/flat/room in } \\
\text { backyard }\end{array}$ & 21 & 2.1 \\
\hline $\begin{array}{l}\text { Informal dwelling/shack in } \\
\text { backyard }\end{array}$ & 24 & 2.3 \\
\hline $\begin{array}{l}\text { Informal dwelling/shack not in } \\
\text { backyard, e.g. in an informal/ } \\
\text { squatter settlement or on farm }\end{array}$ & 225 & 22.0 \\
\hline Room/flatlet & 6 & 0.6 \\
\hline Caravan/tent & 8 & 0.8 \\
\hline Other (specify) & 2 & 0.2 \\
\hline Refused to answer & 20 & 2.0 \\
\hline Total & 1024 & 100 \\
\hline
\end{tabular}

Although $43.8 \%$ of the respondents indicated that they had title deeds (Table 4), in response to another question, approximately 20\% more (63.3\%) indicated that they had ownership title. This corresponds with the $19.9 \%$ who indicated that they did not have title deeds, while $36.3 \%$ either did not know whether they had title deeds or did not answer the question (Table 4).

Table 4. Title deed for the dwelling.

\begin{tabular}{l|rr}
\multicolumn{1}{r|}{ Response } & Frequency & (\%) \\
\hline Yes & 448 & 43.8 \\
No & 204 & 19.9 \\
Refused to answer & 336 & 35.7 \\
Don't know & 6 & 0.6 \\
Total & $\mathbf{1 0 2 4}$ & $\mathbf{1 0 0}$
\end{tabular}

Only $28.8 \%$ of the sampled families indicated that they pay rent, the monthly rental amounts ranging from 150 ZAR (about 9 EUR) to 13,00o ZAR (about 817 EUR). The highest percentage of the sampled families (1.9\%), pay 900 ZAR (about 57 EUR). Only $15.5 \%$ of the 
sampled families who pay rent indicated that they would like to own the house. The highest percentage (16.1\%) indicated that the total number of rooms that the household occupies in all structures of this dwelling including bathrooms, toilets and kitchens are three rooms, while the second highest percentage (15.6\%) indicated the household consists of only one room.

Postmasburg is situated in an arid region, which has a low annual rainfall of $240 \mathrm{~mm}$. According to the national census of 2011, all households have access to water, while $55.9 \%$ have no reliable water supply and have to rely on stagnant water sources, boreholes or municipal water tanks to supplement their primary water sources [22]. Only $18 \%$ of the respondents indicated that they did not have access to piped water inside the dwelling or on site, which is still above the national average of $8.75 \%$, which includes the well-serviced metropolitan areas. It should also be noted that the combined service delivery index was the highest, namely $4.6 \%$ for metropolitan municipalities and lowest, namely $3.3 \%$ for rural municipalities such as Postmasburg [32].

Regarding sanitation, 20.3\% of the respondents have no access to sanitation and are using a bucket system or pit latrines. In the adjacent local municipalities of Siyancuma and !Kheis much higher percentages, namely $47.92 \%$ in Siyacuma and $80.09 \%$ of the residents in !Kheis, are not currently connected to the public sewerage system [33].

Table 5 shows that $21.7 \%$ of the respondents do not have electricity, which is above the national average (15.21\%); and $32.6 \%$ indicated that their refuse is not regularly removed (Table 6), which is substantially higher than the national average of $5.4 \%$ for no refuse removal [29].

Table 5. Access to electricity.

\begin{tabular}{l|rr}
\multicolumn{1}{r|}{ Response } & Frequency & (\%) \\
\hline Yes & 770 & 75.2 \\
No & 222 & 21.7 \\
Refused to answer & 3 & 0.3 \\
Don't know & 29 & 2.9 \\
Total & 1024 & 100
\end{tabular}

Table 6. Regular refuse removal.

\begin{tabular}{l|rr}
\multicolumn{1}{c|}{ Response } & Frequency & \multicolumn{1}{c}{$(\boldsymbol{\%})$} \\
\hline Yes & 666 & 65 \\
No & 334 & 32,6 \\
Refused to answer & 22 & 2,2 \\
Don't know & 2 & 0,2 \\
Total & 1024 & 100
\end{tabular}

\subsection{Qualitative analysis based on interviews}

Qualitative interviews were conducted in 2016. Although 28 interviews were conducted, only those addressing the issues discussed in this paper are listed
(Table 7) and cited. Interviewees were invited to reflect on the impact of mining, municipal service delivery and the contribution of the tripartite partnership in Postmasburg. This section looks at the main themes emerging from the conversations with members of the business community, community leaders, public officials, mining employees and professional planners interviewed during the study. The following discussion reflects on the perceptions and experiences of the interviewees.

[21].

Table 7. Participants cited in the qualitative study

1. Husband and wife business team who distribute their
produce to neighbouring towns
2. Businessperson and director of a local co-op, as well as a
member of the local agricultural union
3. Businessperson
4. Businessperson (and consultant) interviewed
5. Municipal councillor and businessperson
6. Businessperson
7. Professor in geohydrology
8. Tsantsabane municipal official
9. Tsantsabane municipal official
10. Tsantsabane municipal official
11. Spatial Planner in Private Practice who submitted land-
use applications in Postmasburg
12. Tsantsabane municipal official who is employed in the
finance division
13. Kolomela mineworker
14. Municipal official and former mayor
15. Beeshoek mineworker
16. Local Property Agent
17. Headmaster at a school in Postmasburg
18. Headmaster at a school in Beeshoek
19. Employee at a mine
20. Retired Spatial Planner formerly at the provincial
government
21. Spatial Planner in Private Practice who submitted land-
use applications in Postmasburg

\subsubsection{The impact of mining on the town}

The Postmasburg business community (interviewees 1 to 6 ) not only that pointed out the positive but also the negative impacts of mining on the town. A positive impact is that, due to the population increase (see section 4), mostly because of the influx of the mining employees, the farmers, shop owners and pharmacists have a local market for their produce, products and services. Mining employees reported that because of this population growth there had, at a certain point, been a housing shortage in Postmasburg, a result of the high demand for accommodation, particularly due to the influx of mining employees. However, once the mine had become operational, the contractors started to move out and sell their 
properties, leading to declining house prices and therefore more affordable housing in Postmasburg.

A complaint raised by the business community was that the mines could afford to pay higher wages than the local businesses and residents and therefore, the local workforce preferred jobs in the mines, rather than working for the local, small businesses. This brings us to the elephant in the room; namely, what will happen to a mining town like Postmasburg, which relies heavily on mining, when the mine closes down? There is the interim reassurance that Kolomela is a new mine of seven to eight years old and profitable and therefore the mines would not close down in the near future (A geohydrologist - interviewee 7).

Another negative impact of mining is that the influx of people into the town put additional pressure on the service delivery capacity (Tsantsabane municipal official-interviewee 8).

\subsubsection{Municipal governance and finance}

The municipal council squandered funds and was unable to account for how these were spent, to the South African Auditor General (Businessperson interviewees number 3 and 6). In addition to this, the municipal manager was under investigation at the time for alleged tender fraud involving the African National Congress (ANC) Youth League (Businessperson who worked for a construction company but at the time of the study was a consultant - interviewee number 4 ). The community accused the municipality of not having sound financial systems in place and of not issuing invoices. These accusations were confirmed by other interviewees who affirmed that the municipality failed to collect revenue as a result of the lack of necessary systems and an inadequate human resource capacity (Tsantsabane municipal officers-interviewees 9 and 10, and also a spatial planner in private practice who submitted land-use applications in Postmasburg interviewee 11). The relationship between the provincial treasury department and the municipal finance department was dysfunctional (Tsantsabane municipal official who works in the finance division - interviewee 12). It was concurred that the financial division of Tsantsabane lacked capacity.

\subsubsection{Infrastructure and service delivery}

In spite of being located in an arid area, Postmasburg has no water shortage. The boreholes and Sedibeng Water's Gamagara Line provide ample water (Interviewee 13). The community had convinced the mine's management to pump water back into the ground to replenish the underground water level (Businessperson - interviewee 2) but, according to a professor in geohydrology, a national government agreement with Anglo American's Kumba Iron Ore
Limited determined that water should be pumped into the Gamagara Line (Interviewee 7).

The community agreed that despite the low standard of the municipal infrastructure, they were grateful nonetheless to the people maintaining it. It was asserted that the newly established Tsantsabane partnership does not shy away from problems but works towards solutions (Municipal councillor, who also is a local businessperson - interviewee 5). It was stated that the municipality was not sustainable and that the Tsantsabane partnership financed the projects identified in the municipal Integrated Development Plan (Municipal official who is also a former mayor interviewee 14) as well as another municipal official at Tsantsabane - interviewee 9).

Postmasburg could attract more investors if the engineering infrastructure was on par (Municipal councillor and businessperson- interviewee 5). Furthermore, since the municipality does not maintain the existing infrastructure such as roads, sewerage, electricity and water supply, the mine is obliged to undertake these responsibilities (Employee at the Beeshoek Mine- interviewee 15; a businessperson interviewee 6; and a local property agent - interviewee 16). The water pumps are sometimes out of order and at the time of the interviews some of the houses had no running water, despite the fact that the pumps were working and water was available when the mine handed over the houses to the residents (Municipal councillor, who is also a local businessperson - interviewee 5). A pipeline costing 6.5 million ZAR (about 400,ooo EUR) burst because the pump was too strong and the mine repaired it as the municipality did not have the resources or the skills available to fix it.

The municipality only manages to deliver a low level of services (Tsantsabane municipal official interviewed who works in the technical services division - interviewee 10; headmaster at a school in Postmasburg - interviewee 17 and the headmaster at a school in Beeshoek - interviewee 18; Mining employee interviewee 19).

\subsubsection{Spatial Planning}

The Postmasburg Municipal Council made the majority of its decisions in an ad hoc manner and planning was not co-ordinated. Eliciting public participation was also a challenge and therefore residents were unaware of circumstances in Postmasburg (Retired spatial planner who was employed by the Northern Cape Provincial Administration - interviewee 20). Interviewees agreed that the major challenges were the lack of sufficient bulk services to address the rapid growth and that the condition of the existing infrastructure was very poor. They alluded to the strength of the municipality being its ownership of most of the strategically located land. 
As the municipality did not have a spatial planner on its staff there was no one with technical knowledge regarding land-use issues to act on its behalf on related matters (Spatial Planner in Private Practice who submitted land-use applications in Postmasburg interviewee 21). At the time of the interviews the local municipality was preparing a grant application to upgrade the existing networks of electricity, water and sanitation (Tsantsabane municipal official - interviewee 10).

\subsubsection{The impact of the tripartite partnership on Postmasburg}

The interviewed mining employees asserted that the mine wished to engage in partnerships but that there were concerns that if the mine did not meet the set targets it would be blacklisted by the national government. These participants were of the opinion that the mine had to drive development while the municipality should bear the responsibility for change. They were also of the opinion that the mine should oversee joint projects and not merely provide the funding, as the municipality lacked the necessary capacity and leadership, both of which are critical for development. According to these interviewees, who are mining employees and officials, the value of the Tsassamba Partnership, which drives joint services and infrastructure projects, lies in the collaboration between the municipality and the mines, as they are reliant on one another for successful outcomes. Interviewees in the business sector also observed that the Partnership was a suitable vehicle for the municipality to co-operate with the mines to build and develop infrastructure together. They purported that the Partnership fostered a free flow of information and regular meetings.

Interviewees at the Beeshoek Mine drew attention to the Mining Charter, which states that all mining companies are obliged to develop local infrastructure and to invest $3 \%$ of the profits of each mine in the town. Therefore Kolomela invests between nine to eleven million ZAR (about 560,000 to 690,000 EUR) per annum in Postmasburg, while Beeshoek invests three million ZAR (about 190,000 EUR). Kolomela paid its three percent community development status dividends to the trust. Kolomela mine discontinued investment into infrastructure and preferred to invest in community development or poverty-alleviation projects, such as: chicken farm, honey/bee farm and vegetable gardens. This resulted in a strained relationship between Kolomela and the municipality (Kolomela mineworker - interviewee 13).

\section{CONCLUSION}

Ten years after the commencement of the tripartite agreement, the success of this partnership approach is evident to all stakeholders and reflects a process that allowed for a great deal of learning by all parties and, based on the positive results, this is a system that might be replicated with success in other small mining towns. The findings of the quantitative questionnaires indicate that in Postmasburg, the level of certain services such as access to piped water is above the national average and the percentage of respondents without sanitation is well below the average percentages of the adjacent local municipalities. The qualitative interviews illustrated that the significance of the Tsassamba Partnership, which drives joint services and infrastructure projects, lies in the collaboration, as neither the municipality nor the mines would be able to achieve results on their own. This is largely due to the fact that the municipality does not maintain existing infrastructure such as roads, sewerage, electricity and water supply, while the Tsassamba Partnership was successful in maintaining the infrastructure until it was handed over to the municipality. Pursuing equal access to resources will also comply with the implementation of the spatial justice principle of the SPLUMA. In the context of this study, this means that towns such as Postmasburg should be given equal opportunities, rather than national and provincial government concentrating solely on the large metropolitan areas.

\section{REFERENCES}

[1] Marais, J. G. L., Toerien, D. (2012), Classification of South African Towns Revisited. In Donaldson, R. \& Marais, J.G.L (Eds.) Small Town Geographies in Africa: Experiences from South Africa and elsewhere. Nova Science Publishers: New York, pp. 242-250.

[2] Robertson, S., Blackwell, B. (2016), Remote mining towns on the rangelands: Determining dependency within the hinterland. In: The Rangeland Journal, vol. 37, issue 6, pp. 583-596. DOI: 10.1071/RJ15046.

[3] Müller, M., Paasch, A. (2015), When only the coal counts - German co-responsibility for human rights in the South African coal sector. Research by Misereor, Germany. Action Aid South Africa, Johannesburg.

[4] Constitutional Law of the Republic of South Africa (1996), Constitution of the Republic of South Africa, Act no 108 of 1996. Government Printers, Pretoria. Available online at: https://www.ru.ac.za/ media/rhodesuniversity/content/humanresources/doc uments/employmentequity/Constitution\%20of\%2othe \%20Republic\%20of\%20South\%20Africa\%201.pdf

[5] Drewes, J. E. (2017), Convenor of the Tsassamba Partnership. Personal communication and Partnership Minutes. Potchefstroom.

[6] Government Gazette of Republic of South Africa (1998), Local Government Municipal 
Structures Act no 117. Government Printers, Pretoria. Available online at: https://www.gov.za/sites/default/ files/a117-98_o.pdf

[7] Volksblad (2017), Anglo gaan dalk nog van sy $S A$ bates verkoop [Perhaps Anglo is still going to sell more of its SA assets]. Sake (Business) Volksblad.

[8] Healy, P. (2006), Collaborative Planning: Shaping Places in Fragmented Societies. Basingstoke, Palgrave.

[9] Hillier, J., Gunder, M. (2003), Planning fantasies: An exploration of a potential Lacanian framework for understanding development assessment planning. In: Planning Theory, vol. 2, no. 3, pp. 225-248. DOI: 10.1177/147309520323005.

[10] Watson, V. (2009), 'The planned city sweeps the poor away...' Urban planning and 21st century urbanisation. In: Progress in Planning, vol. 72, no. 3, pp. 151-193. DOI: https://doi.org/10.1016/j.progress. 2009.06.002

[11] Van Horen, B. (2002), Planning for institutional capacity building in war-torn areas: The case of Jaffna, Sri Lanka. In: Habitat International, vol. 26, pp. 113-128. Available online at: http://www.chs.ubc.ca/ srilanka/PDFs/Institutional\%2ocapacity\%2obuilding\% 20in\%20war-torn\%20areas.pdf

[12] Engel, E., Fischer, R., Galetovic, A. (2013), The basic public finance of public-private partnerships. In: Journal of the European Economic Association, vol. 11, no. 1, pp. 83-111. Available online at: https://www.nber.org/papers/w13284.pdf

[13] Osei-Kyei, R., Chan, A. P. (2015), Review of studies on the Critical Success Factors for PublicPrivate Partnership (PPP) projects from 1990 to 2013. In: International Journal of Project Management, vol. 33, no. 6, pp. 1335-1346. DOI: https://doi.org/10.1016/ j.ijproman.2015.02.008

[14] Iossa, E., Martimort, D. (2015), The Simple Microeconomics of Public-Private Partnerships. In: Journal of Public Economic Theory, vol. 17, no. 1, pp. 448. Available online at: http://sbf.uibe.edu.cn/docs/ 2018-05/20180518135924586304.pdf

[15] Royal Institution of Chartered Surveyors (RICS) (2012), The future of Public Private Partnerships. London. https://www.rics.org.

[16] Australian Government (2008), National Public Private Partnerships Guidelines: Overview. [Online]. Available at: http://www.infrastructure australia.gov.au /public_private/ppp_policy_guidelines.aspx

[17] PPP Canada (2010-2011), Annual Reports: Public-Private Partnerships. Canada: Ottawa [Online]. Available at: http://www.p3canada.ca/home.php [18] Ndoni, D.B. Elhag, T. (2012), Overcoming the barriers to innovation in PPP/PFI project-based environments. RICS COBRA Conference, 11 - 13 September 2012, Las Vegas.

[19] United Nations (1996), Habitat II - Second United Nations Conference on Human Settlements
"Adequate shelter for all" and "Sustainable human settlements development in an urbanizing world". Istanbul. Available online at: https://www.un.org/ ruleoflaw/wp-content/uploads/2015/10/istanbuldeclaration.pdf

[20] United Nations (2016), Habitat III-Third United Nations Conference on Human Settlements "Housing are occurring in the bi-decennial cycle". Quito, Ecuador. Available online at: https://womenwatch. unwomen.org/eventhabitat-iii-united-nations-conferen ce-housing-and-sustainable-urban-development

[21] Drewes, E., Van Aswegen, M. (2013), National planning in South Africa: A temporal perspective. In: Town and Regional Planning, issue 62, pp. 21-28. DOI: 10.2495/SDP130161.

[22] Department of Minerals and Energy of South Africa (1998), White Paper on the Energy Policy of the Republic of South Africa, Pretoria. Available online at: http://www.energy.gov.za/files/ policies/whitepaper_energypolicy_1998.pdf

[23] Drewes, E. (2015), More explicit regional policy for South Africa, please Mr President. In: Town and Regional Planning, issue 67, pp. 58-67. http://journals. ufs.ac.za/index.php/trp/article/view/581/579, Last accessed June, 15, 2018.

[24] National Planning Commission of South Africa. (2012), National Development Plan 2030 overview: Our future - make it work. Pretoria. Available online at: https://www.poa.gov.za/news/ Documents/NPC\%20National\%20Development\%20Pla n\%2oVision\%202030\%20-lo-res.pdf

[25] Government Gazette of Republic of South Africa (2013), Spatial Planning and Land Use Management Act no 16. Government Printers, Pretoria. Available online at: https://www.sacplan.org.za /documents/SpatialPlanningandLandUseManagement Act2013Act16of2013.pdf

[26] Flyvbjerg, B. (2006), Five misunderstandings about case-study research. In: Qualitative Inquiry, vol. 12, no. 2, pp. 219-245. DOI: 10.1177/1077800405284363 [27] Provincial Government of South Africa (2012), Northern Cape Provincial Spatial Development Framework. Office of the Premier of the Northern Cape, Stakeholder Meeting 15 May 2012, Kimberley. Available online at: http://northerncapepsdf.co.za/ (Viewed on 4 December 2018).

[28] Government Gazette of Republic of South Africa (2002), Mineral and Petroleum Resources Development Act no 28 of 2002. Government Printers, Pretoria. Available online at: http://www.eisourcebook. org/cms/South\%20Africa\%20Mineral\%20\&\%20Petrole um\%2oResources\%2oDevelopment\%20Act\%202002.p df. Last accessed: 4 December 2018.

[29] Northern Cape Provincial Government (2004), Northern Cape Provincial Growth and Development Strategy. Northern Cape Department of Economic Development and Tourism: Kimberley. 
[30] Statistics South Africa (2012), Census data, 1996, 2001 and 2011. Stats SA, Pretoria.

[31] South Africa. Department of Housing (2000), National Housing Code. Government Printers, Pretoria.
[32] Statistics South Africa (2016), Community Survey. Stats SA, Pretoria.

[33] The Local Government Handbook: South Africa (2017), A complete guide to municipalities in South Africa. Yes! Media: Cape Town. 